\title{
The effect of rate and extent of weight loss on urea salvage in obese male subjects
}

\author{
Peter Faber ${ }^{1,2 \star}$, Alexandra M. Johnstone ${ }^{1}$, Eileen R. Gibney ${ }^{3}$, Marinos Elia ${ }^{3}$, R. James Stubbs ${ }^{1}$, \\ Paula L. Roger ${ }^{1}$, Eric Milne ${ }^{1}$, William Buchan ${ }^{1}$ and Gerald E. Lobley ${ }^{1}$ \\ ${ }^{1}$ Rowett Research Institute, Greenburn Road, Bucksburn, Aberdeen AB21 9SB, Scotland, UK \\ ${ }^{2}$ University of Southern Denmark, Odense University, Campusvej 55, DK-5000 Odense C, Denmark \\ ${ }^{3}$ Institute of Human Nutrition, Southampton General Hospital, Tremona Road, Southampton SO16 6YD, England, \\ UK
}

(Received 17 May 2002 - Revised 8 January 2003 - Accepted 10 February 2003)

It is well established that in human subjects a proportion of urea production undergoes hydrolysis in the gastrointestinal tract with release of $\mathrm{N}$ potentially available for amino acid synthesis. Previous studies have suggested adaptive changes in urea kinetics, with more urea-N retained within the metabolic pool during reduced dietary intakes of energy and protein. We therefore investigated the effect of rate and extent of weight loss on adaptive changes in urea kinetics in two groups (each $n$ 6) of obese men (mean age 43 (SD 12) years, BMI 34.8 (SD 2.9$) \mathrm{kg} / \mathrm{m}^{2}$ ) during either total starvation for $6 \mathrm{~d}$ or a very-low-energy diet $(2.55 \mathrm{MJ} / \mathrm{d})$ for $21 \mathrm{~d}$. Subjects were resident in the Human Nutrition Unit of the Rowett Research Institute (Aberdeen, Scotland, UK) and lost 6 and $9 \%$ initial body weight within the starvation and dieting groups respectively. Changes in urea-N metabolism were assessed by stable isotope tracer kinetics using $\left[{ }^{15} \mathrm{~N}^{15} \mathrm{~N}\right]$ urea infused intravenously for $36 \mathrm{~h}$ before, during and after weight loss. In response to weight loss, urea production decreased $(P<0.01)$ by $25 \%$ from 278 to $206 \mu \mathrm{mol}$ urea-N/h per $\mathrm{kg}$ within the dieting group only. However, no changes were observed in the proportion of urea being hydrolysed in the gastrointestinal tract (range 20-25\%) or in the proportion of $\mathrm{N}$ retained for anabolic purposes $(80-85 \%$ urea$\mathrm{N}$ from gastrointestinal hydrolysis) within either group. It was concluded that no adaptive changes in urea kinetics occurred in response to either the different rate or extent of weight loss.

Urea kinetics: Weight loss: Obesity

Although urea is considered an endproduct of protein and amino acid metabolism, mechanisms exist to recover some of this $\mathrm{N}$. This involves entry of urea into the digestive tract, followed by hydrolysis to $\mathrm{NH}_{3}$ that can then be used to support the intestinal microbial population. These microbes can then provide a source of amino acid and nucleic acid-N to non-ruminant animals (e.g. Torallardona et al. 1994, 1996) and human subjects (e.g. Jackson, 1998; Metges et al. 1999). In pigs and rats (Torallardona et al. 1994, 1996) this salvage of urea- $\mathrm{N}$ via the gastrointestinal tract has been shown to contribute to positive $\mathrm{N}$ balance. Although it is now generally accepted that urea can serve as a valid source of $\mathrm{N}$ for amino acid synthesis in animals, the nutritional importance and potential of urea hydrolysis and urea-N recycling in human subjects remains a subject of contention (Jackson, 1994a; Young \& El-Khoury, 1994). Nonetheless, research in human subjects has suggested that adaptive changes in the metabolism of urea occur in response to alterations in dietary protein (Langran et al. 1992; Meakins \& Jackson, 1996). Examples of such adaptation involve a larger proportion of urea production transferred to the gut when subjects are fed lowprotein diets (Langran et al. 1992). This enables more urea-N to be potentially retained within the metabolic pool. In contrast, other studies applying traditional mass transfer and isotope techniques have failed to confirm any significant retention of urea-N for anabolic purposes in human subjects (Long et al. 1978; El-Khoury et al. 1994, 1996; Young et al. 2000).

Adaptations might be anticipated if urea production, hydrolysis and urea- $\mathrm{N}$ retention are part of a regulated mechanism and, indeed, urea movement across cell wall membranes involves specific, and regulated, transporters (Sands, 2002). Furthermore, adaptation might be favoured

\footnotetext{
Abbreviations: AN, urea-nitrogen retained for anabolic purposes; OC, urea returned to hepatic ornithine cycle; UE, urinary urea excretion; UG, urea entry to gastrointestinal tract; UP, urea production; VLED, very-low-energy diet.

* Corresponding author: Dr Peter Faber, fax +44 1224 716629, email faber@ doctors.org.uk
} 
under conditions where $\mathrm{N}$ sparing would be beneficial, for example, where protein supply is either low (Langran et al. 1992) or zero, as with protein-free diets (Young et al. 2000), or during fasting. Such considerations may also extend to weight reduction of obese subjects, where maintenance of lean tissue mass appears to be a priority (Van Gaal, 1998). Such subjects are reported to preferentially conserve protein during energy loss compared with lean individuals (Elia, 1991), with this conservation being a function of initial fat mass (Dulloo et al. 1997). During dieting the relative proportion of body energy stores lost as protein:fat may alter (Elia et al. 1999) and this may involve changes in urea salvage. If such adaptive changes do occur, then these will affect the outcome of the dietary strategies employed. This aspect has been examined in two groups of obese male subjects undergoing either a rapid weight reduction (total starvation), involving extensive net mobilisation of body protein reserves, or a slower rate of weight loss (very-lowenergy diet, VLED), with moderate protein intakes $(50 \mathrm{~g} / \mathrm{d})$ and only limited net protein loss. The effects on urea metabolism have been studied under the pre-, during- and post-weight-loss conditions.

\section{Methods}

\section{Subjects and protocols}

Twelve healthy, obese (BMI $30-40 \mathrm{~kg} / \mathrm{m}^{2}$ ) male subjects, aged 20-55 years, were recruited by newspaper advertisement to participate in two weight-loss studies (six subjects per group). Details of subject characteristics, at baseline, are given in Table 1. Subjects were not on any special religious or medical diet. They were non-smokers and had a recent history of weight stability with a loss or gain of $\leq 2 \mathrm{~kg}$ within the past 3 months. Before enrolment, subjects underwent an independent medical examination that involved measurements of fasted blood glucose, serum cholesterol, standard haematological and clinical biochemistry variables and an electrocardiogram. Exclusion criteria were based on medication and medical information obtained during the in-house medical examination, plus additional checks with the subject's own general practitioner. Subjects were not taking any vitamin or mineral supplements and were medically supervised throughout the study. The study was approved by the Joint Ethical Committee of Grampian Health Board and The University of Aberdeen, Scotland, UK. All subjects were interviewed, informed of the procedures involved and the purpose of the study before signing a written consent form. Subjects were given a gratuity and travelling expenses on completion of the study.

Six different subjects were assigned to each study, to examine two rates of weight loss. In one study (starvation group), subjects were fasted for $6 \mathrm{~d}$ to lose $5 \%$ of their original body weight. In the other study (VLED group), subjects consumed a VLED $(2.55 \mathrm{MJ} / \mathrm{d})$ for 3 weeks to lose $10 \%$ original body weight. The VLED group was assessed after $11 \mathrm{~d}$ (5\% weight-loss period) and again at the end of the weight loss (10\% weight-loss period). After the weight-loss periods, subjects in both groups were maintained at their new lower body weight for 1 week (reduced-maintenance period).

For estimates of daily energy requirements, resting metabolic rate $(\mathrm{MJ} / \mathrm{d})$ was measured by indirect calorimetry $(\mathrm{CV}<5 \%)$ using a ventilated hood system (Deltatrac II, MBM-200; Datex Instrumentarium Corporation, Helsinki, Finland) for a period of $40 \mathrm{~min}$ and calculated from gaseous exchange rates of $\mathrm{O}_{2}$ and $\mathrm{CO}_{2}$ (Elia \& Livesey, 1992). Subject height was measured to the nearest $\mathrm{mm}$ using a stadiometer (Holtain Ltd, Crymych, Dyfedd, Wales, UK). Body weight was measured on a portable digital scale (DIGI DS-410; CMS Weighing Equipment, London, UK) to the nearest $50 \mathrm{~g}$, by a member of staff. Measurement of body weight was undertaken daily, before eating and after emptying the bladder, with each subject wearing the same dressing gown each morning. All food was weighed before and after serving and thus the weight and composition of foods consumed calculated. In order (at bedside) to calculate the intravenous $\left[{ }^{15} \mathrm{~N}^{15} \mathrm{~N}\right]$ urea isotope priming dose and infusion rates, total body water and lean body mass were estimated from anthropometric data (Watson et al. 1980).

Table 1. Baseline characteristics of participants

(Mean values and standard deviations for six subjects per group)

\begin{tabular}{|c|c|c|c|c|c|}
\hline & Mean & SD & Mean & SD & $\begin{array}{c}\text { Statistical significance } \\
\text { of effect: } P\end{array}$ \\
\hline Age (years) & 39 & 13 & 46 & 10 & NS \\
\hline Height $(\mathrm{m})$ & 1.76 & 0.06 & $1 \cdot 75$ & 0.05 & NS \\
\hline Body weight (kg) & $107 \cdot 2$ & 11.5 & $107 \cdot 3$ & $15 \cdot 0$ & NS \\
\hline Fat mass $(\mathrm{kg})$ & $38 \cdot 8$ & 6.5 & $45 \cdot 3$ & $9 \cdot 9$ & NS \\
\hline Systolic blood pressure $(\mathrm{mmHg})$ & 118 & 4 & 137 & 14 & 0.002 \\
\hline Diastolic blood pressure $(\mathrm{mmHg})$ & 77 & 7 & 86 & 10 & NS \\
\hline Resting metabolic rate $(\mathrm{MJ} / 24 \mathrm{~h})$ & 8.50 & $1 \cdot 2$ & $8 \cdot 12$ & $1 \cdot 0$ & NS \\
\hline Fasting cholesterol (mM) & $5 \cdot 0$ & $1 \cdot \overline{1}$ & $5 \cdot 3$ & $1 \cdot 2$ & NS \\
\hline Fasting blood glucose (mM) & $4 \cdot 6$ & 0.5 & $5 \cdot 2$ & 0.4 & 0.032 \\
\hline
\end{tabular}


The equation(s) used were:

$$
\begin{aligned}
\text { total body water (litres) }= & 2.447-0.09516 \times \text { age }(\text { years }) \\
& +10.74 \times \text { height }(\mathrm{m}) \\
& +0.3362 \times \text { weight }(\mathrm{kg}),
\end{aligned}
$$

and

lean body mass $(\mathrm{kg})=$ total body water $(\mathrm{kg}) / 0 \cdot 73$.

Fat-free mass was subsequently assumed to be equivalent to lean body mass.

In addition, body composition was measured by a fourcompartment model (Fuller et al. 1992), including dualenergy X-ray absorptiometry scanning (Norland XR-26, Mark II-high speed pencil beam scanner, equipped with dynamic filtration, with version 2.5 .2 of the Norland software; Norland Corporation, Fort Atkinson, WI, USA), air displacement whole-body plethysmography (BodPod $\AA$ Body Composition System; Life Measurement Instruments, Concord, CT, USA) and total body water by ${ }^{2} \mathrm{H}$ dilution (Pullicino et al. 1990). Subjects were resident in the Human Nutrition Unit throughout the study and were aware of their body weight at each phase.

\section{Starvation study protocol}

For 1 week (maintenance period) the subjects consumed a fixed, medium-fat diet (13\% energy as protein, $35 \%$ as fat and $52 \%$ as carbohydrate), details of which are provided in Table 2. Energy content of the diets was individually calculated (to the nearest $0.5 \mathrm{MJ}$ ) to meet energy requirements at $1.6 \times$ resting metabolic rate, to maintain body weight and nutrient stores (Goldberg et al. 1991). After the maintenance week the subjects fasted (starvation period) for $6 \mathrm{~d}$ with ad libitum access to water or decaffeinated, nonenergy drinks only. After the fasting period the subjects, for 1 week (reduced-maintenance period), consumed a fixed, medium-fat diet (13\% energy as protein, $35 \%$ as fat and $52 \%$ as carbohydrate), again calculated to meet individual energy requirements in order to maintain their new lower body weight. Urea kinetics were measured on three occasions: (1) in the fasted state at the end of maintenance $24-36 \mathrm{~h}$ postprandially; (2) end of the $5 \%$

\begin{tabular}{|c|c|c|}
\hline Diet... & Maintenance* & $\begin{array}{c}\text { Very-low-energy } \\
\text { diet }\end{array}$ \\
\hline Weight $(\mathrm{g} / \mathrm{d})$ & 1970 & 642 \\
\hline Energy (MJ/d) & 13.00 & 2.55 \\
\hline Energy as protein $(\mathrm{MJ} / \mathrm{d})$ & 1.68 & 0.84 \\
\hline Energy as carbohydrate $(\mathrm{MJ} / \mathrm{d})$ & $6 \cdot 75$ & 0.85 \\
\hline Energy as fat (MJ/d) & 4.56 & 0.85 \\
\hline Energy density (kJ/kg) & $6 \cdot 6$ & 39.7 \\
\hline Protein $(\mathrm{g} / \mathrm{d})$ & $99 \cdot 0$ & $49 \cdot 9$ \\
\hline Carbohydrate (g/d) & $123 \cdot 2$ & $52 \cdot 8$ \\
\hline Fat $(g / d)$ & $422 \cdot 1$ & $23 \cdot 1$ \\
\hline
\end{tabular}

Table 2. Diet composition of the maintenance and very-low-energy diet

\footnotetext{
* Maintenance diets were calculated individually as a multiple of resting meta-
} bolic rate; example is for $13 \mathrm{MJ} / \mathrm{d}$ requirements. weight-loss period; (3) end of the reduced-maintenance period 24-36 h postprandially.

\section{Very-low-energy diet protocol}

For 1 week (maintenance period) the subjects consumed a fixed, medium-fat diet, identical to that used in the starvation protocol. After the maintenance period, all subjects consumed a VLED $(2.55 \mathrm{MJ} / \mathrm{d}$, details in Table 2) for 3 weeks, following the recommendations of the Department of Health and Social Security (1987) on the quality and quantity of protein content (i.e. minimum $50 \mathrm{~g}$ protein/d for an adult) in a VLED diet and as required by the Joint Ethical Committee of Grampian Health Board and the University of Aberdeen. The VLED diet was prepared daily by a dietetic assistant, as three meals per $\mathrm{d}$, using normal, recognisable foods. The diet and recipes can be obtained upon request. At the end of the weightloss period ( $10 \%$ weight loss) the subjects consumed, for 1 week (reduced-maintenance period), the same maintenance diet as given to the starvation group. Urea kinetics were measured in the fasted state at the end of maintenance, after $5 \%$ weight loss, after a further $10 \mathrm{~d}$ of the VLED at $10 \%$ weight loss and at the end of the reducedmaintenance period. Urine samples were for all infusions collected $24-36 \mathrm{~h}$ postprandially. The energy from dietary protein was $13 \%$ total energy intake during the periods of maintenance before weight loss and reduced maintenance. The energy from dietary protein during the weight loss period (i.e. VLED) was $33 \%$ total energy intake, provided in the form of beef, poultry and dairy sources.

\section{Control of energy expenditure}

The subjects had compulsory exercise targets to achieve every day during the weight-loss period, in order to maintain habitual levels of energy expenditure. The starvation group volunteers had two cycling periods of $40 \mathrm{~min}$ at $65-75 \mathrm{~W}$ and two step-box sessions to maintain energy expenditure at approximately $1.5-1.6 \times$ resting metabolic rate: similar to an average everyday level of activity (Goldberg et al. 1991). This was necessary because the starvation subjects were resident in a whole-body calorimeter (Johnstone et al. 1996) for the duration of the fast. In the VLED group, volunteers were free-living, and exercised for $40 \mathrm{~min} / \mathrm{d}$ at $75-90 \mathrm{~W}$ on a bicycle ergometer (Tunturi, Helsinki, Finland). The volunteers were requested not to undertake any other strenuous physical activity during the study.

\section{Indicators of compliance}

Body-weight loss, RER and peripheral blood glucose (Accutrend; Boehringer Mannheim, Mannheim, Germany) were all monitored as indicators of compliance to the weight-loss protocol.

\section{$\left[{ }^{15} N^{15} N\right]$ urea tracer infusions}

The $\left[{ }^{15} \mathrm{~N}^{15} \mathrm{~N}\right]$ urea (99 atom \%; Isotech Ltd, Miamisburg, OH, USA) was dissolved to a concentration of $8.1 \mathrm{mM}$ in 
$0 \cdot 15 \mathrm{M}-\mathrm{NaCl}$ and tested for sterility and pyrogenity by an independent pharmaceutical company (Tayside Pharmaceuticals, Dundee, Scotland, UK). An intravenous prime dose of $\left[{ }^{15} \mathrm{~N}^{15} \mathrm{~N}\right]$ urea solution, calculated from estimates of total body water, fat-free mass (Watson et al. 1980) and serum urea concentration was administered via an 18 or $20 \mathrm{G}$ catheter (Venflon ${ }^{\circledR}$; Becton Dickinson Infusion Therapy AB, Helsingborg, Sweden) inserted into a dorsal hand vein, to increase the body $\left.{ }^{15} \mathrm{~N}^{15} \mathrm{~N}\right]$ urea to 0.15 atom $\%$ excess. This was followed by a $22 \mathrm{~h}$ continuous intravenous infusion $(0.35 \mu \mathrm{mol}$ $\left[{ }^{15} \mathrm{~N}^{15} \mathrm{~N}\right]$ urea/kg fat-free mass per $\left.\mathrm{h}\right)$, using a syringe driver (A99; Razel Scientific Instruments, Stamford, CT, USA). All syringes were weighed before and after the infusions to determine the exact delivery rates. The isotope solutions were administered through a $0.22 \mu \mathrm{m}$ filter (Millipore Corporation, Bedford, MA, USA). Urine samples were obtained prior to the infusion (background) and at $2 \mathrm{~h}$ intervals during the last $8 \mathrm{~h}$ of the infusion. All samples were acidified with $4 \mathrm{M}-\mathrm{HCl}$ and stored at $-20^{\circ} \mathrm{C}$ until further analysis. At the end of the infusions subjects were weighed and a venous blood sample taken for the assessment of changes in serum urea concentration.

\section{Chemical analyses}

Total urinary $\mathrm{N}$ concentration was determined by microKjeldahl analysis (Davidson et al. 1970) in daily $24 \mathrm{~h}$ urine collections. Serum urea concentration was measured by a colorimetric method (Crocker, 1967) using a commercially available kit (Sigma Aldrich, Poole, Dorset, UK). Urinary urea concentration was measured by a standard technique (Marsh et al. 1965) using a Technicon Auto Analyser (Technicon Instruments Corporation, Tarrytown, NY, USA).

\section{MS analysis}

Urinary urea for MS analysis was isolated and measured for $\left[{ }^{14} \mathrm{~N}^{14} \mathrm{~N}\right]$ urea, $\left[{ }^{14} \mathrm{~N}^{15} \mathrm{~N}\right]$ urea and $\left[{ }^{15} \mathrm{~N}^{15} \mathrm{~N}\right]$ urea content $(\mathrm{m} / \mathrm{z}$ 28, 29, 30 respectively) using a dual-inlet isotope ratio MS (SIRA 12; VG Isogas, Middlewich, Ches., UK), as previously reported (Sarraseca et al. 1998). Standards of comparable ${ }^{15} \mathrm{~N}^{15} \mathrm{~N}$ enrichment and concentration of urea were measured to allow for non-mono-molecular reactions (Sarraseca et al. 1998). Similar corrections were applied for the contributions of $\left[{ }^{14} \mathrm{~N}^{14} \mathrm{~N}\right]-, \quad\left[{ }^{14} \mathrm{~N}^{15} \mathrm{~N}\right]-$ and $\left[{ }^{15} \mathrm{~N}^{15} \mathrm{~N}\right]$ urea in the original infusate (Sarraseca et al. 1998). Analyses were performed in triplicate for the four urine samples (14-22 h of infusion) at steady-state enrichment ('plateau').

\section{Calculations}

Total dietary energy and $\mathrm{N}$ intake were determined from the weighed intake of food using UK food reference tables (Diet 5; The Robert Gordon University, Aberdeen, Scotland, UK). Total $24 \mathrm{~h} \mathrm{~N}$ loss (total N loss) was computed as the sum of total urinary $\mathrm{N}$ loss plus a fixed $1.5 \mathrm{~g}$ $\mathrm{N} / \mathrm{d}$ for faecal and miscellaneous $\mathrm{N}$ losses (Calloway et al. 1971; Scrimshaw et al. 1972).
For the computation of estimates of urea kinetics on infusion days, $24 \mathrm{~h}$ measured urinary urea excretion (UE) was corrected for changes in the body urea pool as follows (El-Khoury et al. 1994):

$$
\mathrm{UE}_{\mathrm{c}}=\mathrm{UE}-\left(\left(\mathrm{s}-\text { urea }_{\mathrm{s}}-\mathrm{s}-\text { urea }_{\mathrm{e}}\right) / 0.92 \times(\mathrm{TBW})\right),
$$

where $\mathrm{UE}_{\mathrm{c}}$ is the corrected $24 \mathrm{~h}$ urinary urea excretion, s-urea $\mathrm{s}_{\mathrm{s}}$ and $\mathrm{s}$-urea $\mathrm{e}_{\mathrm{e}}$ are the measured serum urea concentrations at the beginning and end of the infusion respectively and TBW is estimated total body water. The factor 0.92 is the fraction of water in serum.

On non-infusion days, no corrections for changes in body urea pool size were made. The estimates of urea kinetics were calculated as previously reported (Lobley et al. 2000) with the urea production rate (UP, $\mu \mathrm{mol} / \mathrm{h}$ per $\mathrm{kg}$ ) as:

$$
\mathrm{UP}=\left(\left(\mathrm{E}_{\mathrm{D} 30} / \mathrm{E}_{\mathrm{U} 30}\right)-1\right) \times \mathrm{D}_{30},
$$

where $D_{30}$ is the infusion rate of $\left[{ }^{15} \mathrm{~N}^{15} \mathrm{~N}\right]$ urea and $E_{D 30}$ and $\mathrm{E}_{\mathrm{U} 30}$ is the enrichment of ${ }^{15} \mathrm{~N}^{15} \mathrm{~N}$ in the administered dose and the collected urine samples at steady state. Urea entry into the gastrointestinal system (UG) was calculated as the difference between UP and $\mathrm{UE}_{\mathrm{c}}$ :

$$
\mathrm{UG}=\mathrm{UP}-\mathrm{UE}_{\mathrm{c}} .
$$

With $\mathrm{u}=\mathrm{UE}_{\mathrm{c}} / \mathrm{UP}$ ( $\mathrm{u}$ is the proportion of urea production excreted in urine), the fraction of urea returned to the ornithine cycle from the gastrointestinal tract was calculated as:

$$
\mathrm{r}=\rho /(1-\mathrm{u}),
$$

where $\rho$ is the $\left[{ }^{14} \mathrm{~N}^{15} \mathrm{~N}\right]$ : [total ${ }^{15} \mathrm{~N}$ ] ratio in urinary urea. The rate of urea returned to the ornithine cycle (OC) was calculated as:

$$
\mathrm{OC}=\mathrm{r} \times \mathrm{UG}
$$

The fraction of UG retained for anabolism (AU) is calculated by the difference:

$$
\mathrm{AU}=1-\mathrm{r} .
$$

The urea-N retained for anabolic purposes (AN) is calculated by multiplying the fraction AU by UG:

$$
\mathrm{AN}=\mathrm{UG} \times \mathrm{AU} .
$$

All values are in $\mu$ mol urea-N/h per $\mathrm{kg}$ unless stated otherwise.

\section{Statistical analysis}

Data analyses were performed using the statistical software package Genstat for Windows, version 4.1 (Lawes Agricultural Trust, Rothamsted, Herts., UK). At comparable times, differences between the groups were detected by unpaired $t$ test. Within the individual groups comparisons between periods were done by ANOVA, blocked for subject with period as treatment. Analysis of covariance was used to analyse for group $\times$ period interactions, with values at maintenance used as covariate. A probability of $P<0.05$ 
was taken as statistically significant. Student's $t$ test was used to analyse if balance data were significantly different from zero.

\section{Results}

\section{Anthropometry}

The starvation group lost, on average, $6 \cdot 1 \mathrm{~kg}(5.6 \%$ original body weight, $P<0.001$ ), whereas the VLED group lost $5.2 \mathrm{~kg}(4.8 \%$ original body weight, $P<0.001)$ and $9.2 \mathrm{~kg}(8.6 \%$ original body weight, $P<0.001)$ at 5 and $10 \%$ weight loss respectively (Table 3 ). The mean reductions in body weight at $5 \%$ weight loss were not different $(P>0.05)$ between the two groups. For the starvation group the four-compartment model predicted that the weight loss was partitioned $46: 54$ between lean:fat. Some caution needs to be exercised, however, as the lean tissue 'loss' includes glycogen (plus associated water) and may be overestimated. For the VLED subjects, lean:fat loss was 31:69 at 5\% weight loss and 18:82 at 10\% weight loss. Thus, the proportion of weight loss as lean tissue was lower within the VLED group and declined as weight loss progressed. Indeed, between 5 and $10 \%$ weight loss lean tissue was preserved $(P<0 \cdot 05)$. Within the starvation group a small $(P=0.025)$ increase of $1.1 \mathrm{~kg}$ was observed during the reduced-maintenance period, but this did not occur for the VLED group. Within the starvation group the decrease $(P<0.05)$ in fat-free mass at completion of the starvation had returned to pre-starvation levels by the end of reduced maintenance $(P>0.05)$. This increase in both body weight $(P<0.05)$ and fat-free mass $(P<0.05)$ is probably due to repletion of the glycogen stores metabolised during fasting. A similar picture was observed for the VLED group where fat-free mass again increased $(P<0.05)$ from $10 \%$ weight loss to the end of reducedmaintenance period even though body weight was stabilised, i.e. further fat loss occurred. Subjects, on average lost 1 and $4 \%$ body fat in the fasting and VLED groups respectively $(P<0 \cdot 05)$.

Resting metabolic rate, RER and peripheral blood glucose

Within both the starvation $(P=0.002)$ and VLED group $(P<0.001)$, resting metabolic rate decreased during weight loss and declined further at the end of the reduced-maintenance period by $6 \cdot 2$ (SD 3.5) and $4 \cdot 3$ (SD $4.6) \%$ for the starvation and VLED groups respectively. RER declined $(P<0.001)$ within the starvation group from 0.85 (SD 0.05) at maintenance to 0.73 (SD 0.02) at the end of starvation, but returned to 0.85 (SD 0.04) by the end of reduced maintenance. The VLED group RER showed similar changes $(P<0.001)$, from 0.85 (SD 0.02) at maintenance to 0.77 (SD 0.03$)$ and 0.74 (SD 0.03) at 5 and $10 \%$ weight loss respectively (both $P<0.05$ ), but returned to 0.83 (SD 0.03 ) by the end of reduced maintenance. Peripheral venous blood glucose did not change $(P>0.05)$ within the starvation group (4.6 (SD 0.46), 4.1 (SD 0.90) and 4.9 (SD 0.83 ) $\mathrm{mm}$ respectively). In contrast, within the VLED group blood glucose declined $(P=0.003)$ from $5.2(\mathrm{SD} 0.40) \mathrm{mm}$ at maintenance to 4.5 (SD 0.35) and 4.5 (SD 0.26) $\mathrm{mm}$ at 5 and $10 \%$ weight loss, before returning to $5.0(\mathrm{SD} 0.39) \mathrm{mM}$ at the end of the reduced maintenance.

\section{Nitrogen balance}

Within the starvation group, both the daily total urinary $\mathrm{N}$ loss and urine urea-N:total urea-N (Table 4) decreased $(P<0.001)$ during the weight-loss period and remained lower during the reduced-maintenance period. Total $\mathrm{N}$ balance was positive during both maintenance $(P=0 \cdot 013)$ and reduced-maintenance $(P=0 \cdot 016)$ periods.

Within the VLED group, the daily $\mathrm{N}$ loss (Table 5) did not decrease until the latter half of the weight-loss period (i.e. from 5 to $10 \%$ weight loss). The daily $\mathrm{N}$ loss was smaller $(P=0.001)$ compared with the $10 \%$ weight-loss

Table 3. Body weight BMI, fat-free mass and fat mass for the starvation and very-low-energy-diet groups§

(Mean values and standard deviations for six subjects per group)

\begin{tabular}{|c|c|c|c|c|c|c|c|c|c|c|c|}
\hline \multirow{2}{*}{ Period... } & \multicolumn{2}{|c|}{ Maintenance } & \multicolumn{2}{|c|}{$5 \%$ weight-loss } & \multicolumn{2}{|c|}{$\begin{array}{c}10 \% \\
\text { weight-loss }\end{array}$} & \multicolumn{2}{|c|}{$\begin{array}{l}\text { Reduced- } \\
\text { maintenance }\end{array}$} & \multirow[b]{2}{*}{$F$} & \multirow{2}{*}{$\begin{array}{c}\text { Statistical } \\
\text { significance } \\
\text { of effect: } P\end{array}$} & \multirow[b]{2}{*}{ SED } \\
\hline & Mean & SD & Mean & SD & Mean & SD & Mean & SD & & & \\
\hline \multicolumn{12}{|l|}{ Starvation group } \\
\hline Body weight (kg) & $107 \cdot 2$ & 11.5 & $101 \cdot 1^{*}$ & $12 \cdot 3$ & - & - & $102 \cdot 4^{*} \dagger$ & 11.9 & 83.98 & $<0.001$ & 0.493 \\
\hline BMI $\left(\mathrm{kg} / \mathrm{m}^{2}\right)$ & $34 \cdot 7$ & 2.5 & $32 \cdot 7^{\star}$ & $2 \cdot 7$ & - & - & $33 \cdot 1^{*} \dagger$ & $2 \cdot 7$ & $64 \cdot 41$ & $<0.001$ & 0.184 \\
\hline Fat-free mass (kg) & $68 \cdot 4$ & $7 \cdot 2$ & $65 \cdot 6^{\star}$ & $7 \cdot 7$ & - & - & $68 \cdot 3 \dagger$ & $7 \cdot 2$ & $20 \cdot 62$ & $<0.001$ & 0.493 \\
\hline \multicolumn{12}{|c|}{ Very-low-energy-diet group } \\
\hline Body weight (kg) & $107 \cdot 3$ & $15 \cdot 0$ & $102 \cdot 1^{*}$ & $14 \cdot 3$ & $98 \cdot 1^{*} \dagger$ & $14 \cdot 2$ & $97 \cdot 9^{*} \dagger$ & $14 \cdot 2$ & $202 \cdot 46$ & $<0.001$ & 0.439 \\
\hline BMI $\left(\mathrm{kg} / \mathrm{m}^{2}\right)$ & 34.9 & 3.5 & $33 \cdot 2^{*}$ & $3 \cdot 3$ & $31.9^{*} \dagger$ & $3 \cdot 3$ & $31.9^{*} \dagger$ & 3.4 & $251 \cdot 11$ & $<0.001$ & 0.128 \\
\hline Fat-free mass $(\mathrm{kg})$ & $62 \cdot 0$ & $7 \cdot 0$ & $60 \cdot 4^{*}$ & $7 \cdot 1$ & $60 \cdot 3^{*}$ & $6 \cdot 9$ & $61.5 † \ddagger$ & $7 \cdot 7$ & $8 \cdot 88$ & $<0.001$ & 0.398 \\
\hline Fat mass $(\mathrm{kg})$ & $45 \cdot 3$ & 9.9 & $41 \cdot 7^{\star}$ & $9 \cdot 6$ & $37 \cdot 9^{*} \dagger$ & $9 \cdot 6$ & $36 \cdot 4^{*} \dagger \ddagger$ & 9.5 & $106 \cdot 06$ & $<0.001$ & 0.549 \\
\hline
\end{tabular}

$F$, ratio of variation associated with the effect of interest to the random variation

Mean values were significantly different from those of the maintenance period: ${ }^{*} P<0.05$.

Mean values were significantly different from those of the $5 \%$ weight-loss period: $\dagger P<0.05$.

Mean values were significantly different from those of the $10 \%$ weight-loss period: $\ddagger P<0.05$.

$\S$ For details of subjects, diets and procedures, see Tables 1 and 2 and p. 222. 
Table 4. Starvation group: daily energy and nitrogen intake, nitrogen loss and nitrogen balance§ (Mean values and standard deviations for six subjects)

\begin{tabular}{|c|c|c|c|c|c|c|c|c|c|}
\hline \multirow[b]{3}{*}{ Period... } & \multicolumn{6}{|c|}{ Starvation group } & \multirow[b]{3}{*}{$F(3,5)$} & \multirow{3}{*}{$\begin{array}{c}\text { Statistical } \\
\text { significance } \\
\text { of effect: } P\end{array}$} & \multirow[b]{3}{*}{ SED } \\
\hline & \multicolumn{2}{|c|}{ Maintenance } & \multicolumn{2}{|c|}{$5 \%$ weight-loss } & \multicolumn{2}{|c|}{$\begin{array}{l}\text { Reduced- } \\
\text { maintenance }\end{array}$} & & & \\
\hline & Mean & SD & Mean & SD & Mean & SD & & & \\
\hline Energy intake (MJ/d) & $13 \cdot 33$ & 1.52 & $0 \cdot 00^{*}$ & 0.0 & $10 \cdot 06^{*} \dagger$ & $1 \cdot 13$ & 3.85 & $<0.001$ & 0.424 \\
\hline$N$ intake $(g / d)$ & $16 \cdot 30$ & 1.55 & $0 \cdot 00^{\star}$ & 0.0 & $13.03 \dagger$ & 1.43 & $26 \cdot 81$ & $<0.001$ & $2 \cdot 29$ \\
\hline Urea-N loss (g/d) & $10 \cdot 33$ & 1.06 & $8 \cdot 37^{\star}$ & 0.97 & $5 \cdot 52^{*} \dagger$ & 0.99 & $47 \cdot 48$ & $<0.001$ & 0.497 \\
\hline Urea-N/urinary $\mathrm{N}$ loss (\%) & 78.02 & 4.00 & $66 \cdot 98^{*}$ & $3 \cdot 01$ & $69 \cdot 02^{*}$ & $7 \cdot 15$ & $10 \cdot 87$ & $<0.001$ & 2.77 \\
\hline $\mathrm{N}$ balance $(\mathrm{g} / \mathrm{d})$ & $1.52 \ddagger$ & 0.98 & $-12 \cdot 32^{\star} \ddagger$ & $1 \cdot 27$ & $2 \cdot 88 † \ddagger$ & 1.99 & $47 \cdot 27$ & $<0.001$ & 1.53 \\
\hline
\end{tabular}

Mean values were significantly different from those of the maintenance period: ${ }^{*} P<0.05$.

Mean values were significantly different from those of the $5 \%$ weight-loss period: $+P<0.05$.

Mean values were significantly different from zero (Student's $t$ test): $\ddagger P<0.05$.

$\S$ For details of subjects, diets and procedures, see Tables 1 and 2 and p. 222.

Table 5. Very-low-energy-diet group: daily energy and nitrogen intake, nitrogen loss and balancell (Mean values and standard deviations for six subjects)

\begin{tabular}{|c|c|c|c|c|c|c|c|c|c|c|c|}
\hline \multirow[b]{3}{*}{ Period... } & \multicolumn{8}{|c|}{ VLED group } & \multirow[b]{3}{*}{$F(3,5)$} & \multirow{3}{*}{$\begin{array}{l}\text { Statistical } \\
\text { significance } \\
\text { of effect: } P\end{array}$} & \multirow[b]{3}{*}{ SED } \\
\hline & \multicolumn{2}{|c|}{ Maintenance } & \multicolumn{2}{|c|}{$5 \%$ weight-loss } & \multicolumn{2}{|c|}{$10 \%$ weight-loss } & \multicolumn{2}{|c|}{$\begin{array}{l}\text { Reduced- } \\
\text { maintenance }\end{array}$} & & & \\
\hline & Mean & SD & Mean & SD & Mean & SD & Mean & SD & & & \\
\hline Energy intake (MJ/d) & 12.94 & $1 \cdot 37$ & $2.55^{\star}$ & 0.00 & $2.55^{\star}$ & 0.00 & $10 \cdot 12^{*} \dagger \ddagger$ & $1 \cdot 26$ & 1.99 & $<0.001$ & 0.482 \\
\hline $\mathrm{N}$ intake $(\mathrm{g} / \mathrm{d})$ & $15 \cdot 33$ & 1.05 & $8 \cdot 20^{*}$ & 0.00 & $8 \cdot 20^{*}$ & 0.00 & $10 \cdot 35^{\star} \dagger \ddagger$ & 1.20 & 14.63 & $<0.001$ & 1.64 \\
\hline Urea-N loss (g/d) & 9.82 & $2 \cdot 20$ & $9 \cdot 82$ & 0.94 & 6.65 & 1.09 & 4.48 & 1.86 & $74 \cdot 70$ & $<0.001$ & 0.427 \\
\hline Urea-N/urinary $\mathrm{N}$ loss (\%) & 76.67 & 0.08 & $78 \cdot 33$ & 0.04 & 73.67 & 0.08 & 71.00 & 0.11 & 1.60 & 0.197 & 0.03 \\
\hline $\mathrm{N}$ balance $(\mathrm{g} / \mathrm{d})$ & $1.55 \S$ & 0.66 & $-5 \cdot 42^{\star} \S$ & 0.94 & $-2 \cdot 33^{\star}+\S$ & 0.97 & $2.68 \dagger \neq \S$ & $1 \cdot 28$ & 94.23 & $<0.001$ & 0.54 \\
\hline
\end{tabular}

Mean values were significantly different from those of the maintenance period: ${ }^{*} P<0.05$.

Mean values were significantly different from those of the $5 \%$ weight-loss period: $\dagger P<0.05$

Mean values were significantly different from those of the $10 \%$ weight-loss period: $\pm P<0.05$.

Mean values were significantly different from zero (Student's $t$ test): $\S P<0.05$.

$\|$ For details of subjects, diets and procedures, see Tables 1 and 2 and p. 222

period. $\mathrm{N}$ balance was less negative $(P=0.002)$ during the 10 compared with the $5 \%$ weight-loss period. During the reduced-maintenance period $\mathrm{N}$ balance was positive $(P=0.004)$ with no significant changes $(P>0.05)$ observed in the urinary urea-N:total urinary $\mathrm{N}$ loss ratio within the VLED group.

Between the studies, there were no differences in either $\mathrm{N}$ loss or $\mathrm{N}$ balance at comparable periods. During the $5 \%$ weight-loss period, urinary urea- $\mathrm{N}$ :total urinary $\mathrm{N}$ was lower $(P=0.002)$ for the starvation group.

\section{Urea kinetics}

All urea measurements (Tables 6 and 7) were similar between the two groups during the pre-weight-loss period (maintenance) and for most other comparable periods.

Serum-urea concentration decreased $(P<0.05)$ in the starvation group after the reduced-maintenance period. In contrast, within the VLED group, serum urea concentration decreased $(P<0.05)$ after both 5 and $10 \%$ weight loss and then remained lower during reduced maintenance.

During starvation, UP was unaltered compared with the maintenance period, but was lower $(P=0.01)$ in the reduced-maintenance period. A different pattern was observed for the VLED group, where UP decreased $(P<0.001)$ after 5\% weight loss and this lower rate of urea production was then maintained $(P<0.05)$ during both $10 \%$ weight-loss and reduced-maintenance periods.

Across the starvation group there were no changes in UE, while for the VLED group, UE paralleled results for UP, with a decrease $(P<0.001)$ between maintenance and $5 \%$ weight loss. These parallel decreases meant that the urinary urea loss:urea production (UE:UP) remained constant within the groups before, during and after the weight-loss periods. At $5 \%$ weight loss the fraction of urea hydrolysis was $18.7 \%$ during starvation and $23.5 \%$ in the VLED group. Individuals showed a range in this ratio (approximately $5-30 \%$ for starvation and approximately $10-40 \%$ for VLED) at $5 \%$ weight loss, but maintained their ratio throughout the various phases of the study. For the 
Table 6. Starvation group: urea kinetics at maintenance, $5 \%$ weight loss and reduced maintenance $\dagger$ (Mean values and standard deviations for six subjects)

\begin{tabular}{|c|c|c|c|c|c|c|c|c|c|}
\hline \multirow[b]{3}{*}{ Period. . } & \multicolumn{6}{|c|}{ Starvation group } & \multirow[b]{3}{*}{$F(2,10)$} & \multirow{3}{*}{$\begin{array}{l}\text { Statistical } \\
\text { significance } \\
\text { of effect: } P\end{array}$} & \multirow[b]{3}{*}{ SED } \\
\hline & \multicolumn{2}{|c|}{ Maintenance } & \multicolumn{2}{|c|}{$5 \%$ weight-loss } & \multicolumn{2}{|c|}{$\begin{array}{l}\text { Reduced- } \\
\text { maintenance }\end{array}$} & & & \\
\hline & Mean & SD & Mean & SD & Mean & SD & & & \\
\hline Serum urea $(\mathrm{mmol} / \mathrm{l})$ & 5.11 & 0.79 & 5.09 & 0.89 & $4.45^{\star}$ & 0.73 & 4.89 & 0.033 & 0.24 \\
\hline UP ( $\mu \mathrm{mol}$ urea-N/h per kg) & $307 \cdot 2$ & $45 \cdot 6$ & $282 \cdot 2$ & 49.2 & $250 \cdot 0^{*}$ & $30 \cdot 8$ & 7.47 & 0.010 & 14.84 \\
\hline UE ( $\mu \mathrm{mol}$ urea-N/h per kg) & 239.6 & 31.4 & 229.0 & 39.4 & $201 \cdot 2$ & $24 \cdot 2$ & 3.65 & 0.065 & 14.64 \\
\hline UG ( $\mu \mathrm{mol}$ urea-N/h per kg) & 67.9 & $21 \cdot 0$ & 53.4 & $26 \cdot 0$ & $48 \cdot 6$ & $23 \cdot 2$ & $1 \cdot 71$ & 0.230 & $10 \cdot 64$ \\
\hline UG/UP (\%) & $21 \cdot 8$ & 4.3 & $18 \cdot 7$ & 8.2 & $19 \cdot 2$ & $8 \cdot 1$ & 0.37 & 0.697 & 3.94 \\
\hline OC ( $\mu$ mol urea-N/h per kg) & $11 \cdot 0$ & $6 \cdot 8$ & $11 \cdot 0$ & 4.8 & 5.4 & 4.8 & $2 \cdot 25$ & 0.156 & 3.08 \\
\hline AN ( $\mu \mathrm{mol}$ urea-N/h per kg) & $56 \cdot 4$ & $22 \cdot 0$ & $42 \cdot 2$ & $26 \cdot 8$ & $43 \cdot 2$ & 23.2 & 1.36 & 0.300 & 6.46 \\
\hline UE/ÜP (\%) & 78 & $2 \cdot 0$ & 82 & $8 \cdot 2$ & 81 & $8 \cdot 1$ & 0.40 & 0.682 & 4.00 \\
\hline $\mathrm{AU}(\%)$ & $82 \cdot 6$ & $12 \cdot 6$ & $80 \cdot 9$ & $9 \cdot 3$ & $87 \cdot 1$ & $9 \cdot 8$ & 0.72 & 0.510 & $5 \cdot 36$ \\
\hline
\end{tabular}

UP, urea production; UE, urinary urea excretion; UG, urea entry to gastrointestinal tract; OC, urea returned to hepatic ornithine cycle; AN, urea-nitrogen retained for anabolic purposes; $A U$, fraction of UG retained for anabolism.

Mean values were significantly different from those of the maintenance period: ${ }^{*} P<0.05$.

†For details of subjects, diets and procedures, see Tables 1 and 2 and p. 222.

Table 7. Very-low-energy-diet group: urea kinetics at maintenance, $5 \%$ weight loss, $10 \%$ weight loss and reduced maintenanceł (Mean values and standard deviations for six subjects)

\begin{tabular}{|c|c|c|c|c|c|c|c|c|c|c|c|}
\hline \multirow[b]{3}{*}{ Period... } & \multicolumn{8}{|c|}{ VLED group } & \multirow[b]{3}{*}{$F(3,15)$} & \multirow{3}{*}{$\begin{array}{l}\text { Statistical } \\
\text { significance } \\
\text { of effect: } P\end{array}$} & \multirow[b]{3}{*}{ SED } \\
\hline & \multicolumn{2}{|c|}{ Maintenance } & \multicolumn{2}{|c|}{$5 \%$ weight-loss } & \multicolumn{2}{|c|}{$10 \%$ weight-loss } & \multicolumn{2}{|c|}{$\begin{array}{l}\text { Reduced- } \\
\text { maintenance }\end{array}$} & & & \\
\hline & Mean & SD & Mean & SD & Mean & SD & Mean & SD & & & \\
\hline Serum urea $(\mathrm{mmol} / \mathrm{l})$ & $5 \cdot 16$ & 0.70 & $4 \cdot 36^{\star}$ & 0.91 & $4.06^{*} \dagger$ & 0.78 & $4 \cdot 00^{\star}$ & 0.51 & $27 \cdot 33$ & $<0.001$ & 0.14 \\
\hline UP ( $\mu$ mol urea-N/h per kg) & $278 \cdot 0$ & $44 \cdot 0$ & $205 \cdot 6^{*}$ & 37.4 & $187 \cdot 2^{\star}$ & 39.8 & $198 \cdot 0^{\star}$ & $22 \cdot 4$ & $38 \cdot 10$ & $<0.001$ & 9.44 \\
\hline UE ( $\mu \mathrm{mol}$ urea-N/h per kg) & 207.4 & 34.4 & $157 \cdot 8^{\star}$ & $34 \cdot 0$ & $144 \cdot 8^{\star}$ & $42 \cdot 2$ & $158 \cdot 8^{\star}$ & $20 \cdot 4$ & $9 \cdot 82$ & $<0.001$ & $12 \cdot 42$ \\
\hline UG ( $\mu$ mol urea-N/h per kg) & $70 \cdot 6$ & $17 \cdot 4$ & $48 \cdot 0^{*}$ & $20 \cdot 6$ & $42 \cdot 4^{\star}$ & $26 \cdot 8$ & $39 \cdot 2^{*}$ & 13.4 & 3.54 & 0.041 & $10 \cdot 68$ \\
\hline UG/UP (\%) & $25 \cdot 5$ & 4.7 & 23.5 & $10 \cdot 4$ & $22 \cdot 8$ & $14 \cdot 2$ & 19.8 & 6.5 & 0.38 & 0.769 & 5.39 \\
\hline OC ( $\mu$ mol urea-N/h per kg) & 13.6 & 3.4 & $6 \cdot 8^{*}$ & 3.2 & $6 \cdot 8^{\star}$ & $5 \cdot 0$ & $5 \cdot 4^{\star}$ & $2 \cdot 2$ & $10 \cdot 72$ & $<0.001$ & 1.58 \\
\hline AN ( $\mu$ mol urea-N/h per kg) & $57 \cdot 2$ & $14 \cdot 4$ & $41 \cdot 2$ & $18 \cdot 4$ & $35 \cdot 6$ & $22 \cdot 8$ & $35 \cdot 0$ & $11 \cdot 6$ & 2.49 & $0 \cdot 100$ & $6 \cdot 38$ \\
\hline UE/ÜP (\%) & 75 & 4.7 & 77 & $10 \cdot 4$ & 77 & $14 \cdot 2$ & 80 & 6.5 & 0.38 & 0.767 & $5 \cdot 36$ \\
\hline $\mathrm{AU}(\%)$ & $80 \cdot 9$ & 2.5 & $85 \cdot 6$ & $4 \cdot 0$ & 83.2 & $7 \cdot 2$ & $86 \cdot 4$ & 3.9 & 3.01 & 0.063 & 2.05 \\
\hline
\end{tabular}

VLED, very-low-energy-diet; UP, urea production; UE, urinary urea excretion; UG, urea entry to gastrointestinal tract; OC, urea returned to hepatic ornithine cycle; AN, urea-nitrogen retained for anabolic purposes; AU, fraction of UG retained for anabolism.

Mean values were significantly different from those of the maintenance period: ${ }^{\star} P<0.05$.

Mean value was significantly different from that of the $5 \%$ weight-loss period: $\dagger P<0.05$

$\ddagger$ For details of subjects, diets and procedures, see Tables 1 and 2 and p. 222.

starvation group, there were no changes observed in any of the other aspects of urea metabolism (i.e. UG, OC, AN) between maintenance, weight loss or reduced maintenance. In contrast, for the VLED group, UG declined $(P=0 \cdot 041)$ after $5 \%$ weight loss, but the proportion of UP entering the gastrointestinal tract (i.e. UG/UP) was unaltered $(P>0.05)$. Over the same period, OC decreased $(P<0 \cdot 001)$. These changes in UG and OC were sustained during the weight-loss and reduced-maintenance periods.

The exceptions were UP and UE, which were higher within the starvation group, both after $5 \%$ weight loss (UP $P=0.013$, UE $P=0.007$ ) and at the end of reduced maintenance (UP $P=0.007$, UE $P=0.008$ ). Irrespective of dietary intake in both groups, the proportion of retained urea-N (AN) remained between 80 and $85 \%$ of UG with AN equivalent to approximately $10 \mathrm{~g}$ protein/d (34-56 $\mu \mathrm{mol}$ urea-N/kg per d).

\section{Discussion}

The objective of the present study was to investigate whether adaptive changes in urea metabolism occurred in obese male subjects in response to two different rates and extents of weight loss, induced by either total starvation or a VLED. The two diet regimens produced different responses in urea kinetics, e.g. starvation did not alter urea production while the VLED caused a marked reduction. On both treatments, however, urea production was lower in the post-fasting maintenance phase compared with pre-fasting. Despite these various changes, the ratio of 
urea production hydrolysed in the gut remained constant, although the absolute rates did change. The fraction (AU) of urea hydrolysis available for either anabolism (via microbial sources) or involved in transamination reactions was high, approximately $80-85 \%$, for both the starvation and VLED groups respectively, and unaltered during the various dietary phases.

The measured urea production of 200-300 $\mu \mathrm{mol}$ urea-N/kg body weight per $\mathrm{h}$ is lower than previously reported rates of $400-500 \mu \mathrm{mol}$ urea-N/kg body weight per $\mathrm{h}$ during energy and $\mathrm{N}$ equilibrium (Varcoe et al. 1975; Long et al. 1978; Jackson et al. 1984; El-Khoury et al. 1994; Child et al. 1997). Most of these studies, however, have been conducted in lean individuals, thus confounding comparisons between lean and obese subjects when production rates are expressed in relation to body weight. When expressed in relation to fat-free body mass (Watson et al. 1980) the urea production rates at maintenance intake were approximately $410-450 \mu \mathrm{mol}$ urea-N/kg fat-free mass per $\mathrm{h}$ for the obese subjects within the two treatment groups. This compares with values of 460-575 $\mu \mathrm{mol}$ urea-N/kg fat-free mass per $\mathrm{h}$ for lean subjects (Varcoe et al. 1975; Long et al. 1978; Jackson et al. 1984; El-Khoury et al. 1994; Child et al. 1997) assuming body fat to be $15 \%$ total body weight. Hence, when expressed in relation to fat-free body mass, urea production truly may be lower in obese when compared with lean subjects. During conditions of energy restriction such a difference may become even more significant and would support the hypothesis that during weight loss obese individuals mobilise a smaller proportion of energy from protein compared with lean subjects (Elia, 1991).

Previous studies have examined the effect of dietary manipulations on urea metabolism. Generally, urea production has been shown to exceed urinary urea excretion by approximately 20-30\% (Jackson et al. 1993; El-Khoury et al. 1994; Forslund et al. 1998; Young et al. 2000), with the fraction of urea not excreted in the urine being hydrolysed in the gastrointestinal tract. Despite the general acceptance of these findings there has been considerable controversy recently about the factors that regulate UP and urea hydrolysis. For example, Jackson (1998, 1999) suggested that UP was independent of protein intake (Child et al. 1997) and that urea hydrolysis was important in the control of body $\mathrm{N}$ homeostasis. These views have been vigorously challenged and linear relationships demonstrated between UP and both protein intake and leucine oxidation (Young et al. 2000). These latter authors also claimed a linear relationship between protein intake and urea hydrolysis.

The current results extend previous comparisons to the $6 \mathrm{~d}$ fasted condition and here there was no difference in UP compared with daily intakes of approximately $90 \mathrm{~g}$ protein prior to starvation. While this observation would support the conclusions of Jackson (1998, 1999), under the reduced maintenance conditions that involved approximately 40 and $25 \%$ reductions in protein and energy intake, UP was significantly reduced. Similarly, during the VLED study the decrease in both energy and protein intake from the pre-weight loss phase also showed a 26-33\% decrease in UP. It is not possible to separate effects of protein and energy on these rates of UP, but clearly the system is responsive and, in general, these results would support the alternative hypotheses of Young et al. (2000).

The key to this debate probably involves the extent to which either dietary protein and/or energy is restricted and how much tissue protein needs to be mobilised to maintain normal homeostatic function. UP arises from both dietary and endogenous sources, the former demonstrated by the fact that UP increases with high $\mathrm{N}$ intakes (Forslund et al. 1998). Nonetheless, at adequate to high protein (and energy) intakes mobilisation of body protein reserves is relatively constant and thus a good relationship between $\mathrm{N}$ intake and UP would be expected (Young et al. 2000). During starvation or lowprotein (or-energy) intakes, as glycogen stores become depleted, some protein and amino acids are mobilised to provide glyconeogenic precursors (Cahill, 1970; Owen et al. 1998), consequently, maintaining UP similar to fed values. In these circumstances, the relationship between UP and $\mathrm{N}$ intake is infinity (i.e. no linear relationship; Langran et al. 1992; Meakins \& Jackson, 1996).

These concepts are clearly seen in the current study, with high rates of UP, supported by extensive tissue protein catabolism, maintained during the starvation phase to ensure synthesis of glucose for vital brain and kidney functions. In contrast, within the VLED group the energy and protein intake during weight loss would have been sufficient to avoid mobilisation of endogenous protein stores for gluconeogenesis and, within this group, the decrease in dietary protein intake of $5.0 \mathrm{~g} \mathrm{~N} / \mathrm{d}$ was accompanied by a reduction in UP rate of $2.8 \mathrm{~g}$ urea-N/d. This small discrepancy between the decrease in $\mathrm{N}$ intake and urea-N production during the weight loss of the VLED group was also observed for comparisons between the maintenance and reduced-maintenance periods for both groups, with decreases in UP of approximately 2.0 and $2.8 \mathrm{~g}$ urea-N/d for the starvation and VLED subjects when $\mathrm{N}$ intake decreased by 3.3 and $5.5 \mathrm{~g} \mathrm{~N} / \mathrm{d}$ respectively. While such differences may be a consequence of the current experimental design, with urea kinetics measured at the end of a $36 \mathrm{~h}$ fast, other studies have also reported that the decline in UP can be less than the decrease in dietary protein intake (Langran et al. 1992; Meakins \& Jackson, 1996). The reason for this is unclear.

In studies on dietary restriction there is a close association between energy and protein intake, as shown by the reduced $\mathrm{N}$ retention (and probably increased UP) at a constant level of protein intake when dietary energy intake was lowered (Young et al. 1992). Similarly, when the protein intake of subjects was altered from 7 to $14 \%$ total dietary energy intake (Langran et al. 1992), the proportion of UG decreased from 64 to $46 \%$. Furthermore, dietary supplementation with urea can result in additional $\mathrm{N}$ retention when subjects are fed a diet low in protein but adequate for energy (Meakins \& Jackson, 1996). Together, these observations have led to the suggestion that gastrointestinal urea hydrolysis contributes positively to $\mathrm{N}$ balance in human subjects fed diets limited in energy (Jackson, 1994b) and protein (Jackson, 1991, 1998) and that such a mechanism may be adaptive. 
The fraction of UP that is hydrolysed within the gut can vary from 8 to $64 \%$ (Langran et al. 1992; El-Khoury et al. 1994; Forslund et al. 1998; Young et al. 2000), with both low (8\%, Young et al. 2000) and high (64\%, Langran et al. 1992) proportions observed with proteinfree or low-protein diets. As discussed by Young et al. (2000), care must be taken to ensure both good tracer kinetics, including changes in body urea pool size over the duration of measurement, and good collection of urine as the hydrolysis component is obtained by difference. In the current study, and over a wide range of protein intakes (zero to adequate, $90 \mathrm{~g} / \mathrm{d}$ ) the fraction of urea production transferred to the gut was remarkably constant $(20-25 \%)$. As UP varied, however, the absolute intestinal transfer did alter. This resulted in lower inflows to the gut lumen during the weight-reduction phases and, as the fraction available for anabolism did not change, then the amount salvaged as potentially productive $\mathrm{N}$ also decreased. Thus, there was not an adaptation to improve $\mathrm{N}$ retention between maintenance and reduced-maintenance phases, nor during the VLED weight loss periods. Furthermore, this conservation was maintained during the starvation phase, i.e. there was no increase, as might be expected if adaptation of urea hydrolysis was an important factor in trying to maintain $\mathrm{N}$ balance under conditions of low (or zero) dietary protein intake.

In terms of absolute contribution, the current results suggest that anabolic use of urea- $\mathrm{N}$ may contribute the equivalent of approximately $10 \mathrm{~g}$ protein/d to the body metabolic pool, with these quantities relatively constant between various dietary regimens and phases. Furthermore, this represents a substantial proportion of urea-N that enters the gut and might imply an important role for urea salvage in $\mathrm{N}$ homeostasis. Such values need to be treated with caution, however. First, because urea-N retained (AN) is derived indirectly as the difference between the two measures UG and OC, any differential changes in these two variables will affect $\mathrm{AN}$ accordingly. Second, the reversible transamination between $\mathrm{NH}_{3}$ and the oxo-acids of amino acids (Jackson et al. 1981; ElKhoury et al. 1996) can lead to an overestimation of retained urea-N for anabolic purposes. The extent of such transamination has been demonstrated following administration of either ${ }^{15} \mathrm{NH}_{3}$ (Furst et al. 1970; Weijs et al. 1996) or $\left[{ }^{15} \mathrm{~N}\right]$ amino acids (Jahoor et al. 1988). Nevertheless, a number of studies (Yaboah et al. 1996; Gibson et al. 1997; Metges et al. 1999; Millward et al. 2000) have shown transfer of ${ }^{15} \mathrm{~N}$ from $\mathrm{NH}_{3}$ or urea into the non-transaminating amino acid lysine, i.e. lysine is synthesised de novo by the micro-organisms within the digestive tract and this becomes available for bodytissue gain. These various reports have shown large inter-individual variations, however, and the average contribution from gastrointestinal bacteria as suppliers of lysine (and presumably other amino acids) to meet requirements (World Health Organization, 1985) appears relatively small (Metges et al. 1999; Millward et al. 2000). Similarly, studies in growing rats also indicated only a small fraction of daily lysine requirements is obtained by such synthesis de novo (Torallardona et al. 1996). The proportional contribution of synthesis de novo to daily requirements of essential amino acids may be different in adult human subjects, however, where only maintenance needs have to be met.

In the present studies, the constancy in the proportion of UP undergoing hydrolysis within the gastrointestinal tract (i.e. UG/UP) indicates that no adaptive changes in the re-utilisation of urea-N for anabolic purposes occurred. In addition, as most (80-85\%) of the urea-N entering the gastrointestinal tract was already returned as an anabolic form, even under maintenance conditions, then there was limited flexibility for improvement although, in other studies (usually involving subjects treated with antibiotics), AU (=AN/UG) can be as low as $10 \%$ (Mitch et al. 1977; Long et al. 1978) and may be more responsive to manipulation. Again, caution in interpretation is necessary. For example, the imposed ethical constraints meant that, during dietary restriction for the VLED group, there was a reduction in absolute energy intake but with a greater proportion (33v. 13\%) from protein. Thus, any alterations in urea kinetics (both absolute and proportional) in response to lowered energy intake may have been countered by opposite changes linked to increased protein supply, i.e. adaptive changes may have been masked. This concern was not relevant for the starved subjects and, again, no adaptive changes in urea metabolism were observed during weight loss. Furthermore, in both groups, absolute and proportional values were similar between the end of weight loss and during the reduced-maintenance period and these provide indirect support for non-adaptive changes. Instead, the results suggest that any responses in the re-use of urea-N for anabolic purposes will depend more on the absolute rates of UP and entry into the gastrointestinal tract.

\section{Acknowledgements}

The present study was supported by Slimming World and SERAD (Scottish Executive Environment and Rural Affairs Department) as part of the core budget to the Rowett Research Institute.

\section{References}

Cahill GF (1970) Starvation in man. New Eng J Med 19, 668-675.

Calloway D, Odell A \& Margen S (1971) Sweat and miscellaneous nitrogen losses in human balance studies. J Nutr 101, $775-786$.

Child S, Soares M, Reid M, Persaud C, Forrester T \& Jackson AA (1997) Urea kinetics varies in Jamaican women and men in relation to adiposity, lean body mass and protein intake. Eur J Clin Nutr 57, 107-115.

Crocker CL (1967) Rapid determination of urea nitrogen in serum or plasma without deproteinization. Am J Med Technol 33, $361-365$.

Davidson J, Mathieson J \& Boyne AW (1970) The use of automation in determining nitrogen by the Kjeldahl method, with calculations by computer. Analyst 95, 181-193.

Department of Health and Social Security (1987) The Use of 
Very-Low-Calorie Diets in Obesity. London: H. M. Stationery Office.

Dulloo AG, Jacquet J \& Girardier L (1997) Poststarvation hyperphagia and body fat overshooting in humans: a role for feedback signals from lean and fat tissues. Am J Clin Nutr 65, 717-723.

Elia M (1991) Effect of starvation and very low calorie diets on protein-energy interrelationships in lean and obese subjects. In Protein-Energy Interactions, pp. 249-284 [N Scrimshaw and B Schurch, editors]. Lausanne: Nestle Foundation.

Elia M \& Livesey G (1992) Energy expenditure and fuel selection in biological systems: The theory and practice of calculations based on indirect calorimetry and tracer methods. In Metabolic Control of Eating, Energy Expenditure and the Bioenergetics of Obesity, pp. 68-131 [A Simopoulus, editor]. Basel: Karger.

Elia M, Stubbs RJ \& Henry CJ (1999) Differences in fat, carbohydrate, and protein metabolism between lean and obese subjects undergoing total starvation. Obes Res 7, 597-604.

El-Khoury A, Ajami A, Fukagawa N, Chapman T \& Young VR (1996) Diurnal pattern of the interrelationships among leucine oxidation, urea production and hydrolysis in humans. Am J Physiol 271, E563-E573.

El-Khoury A, Fukagawa N, Sanchez M, et al. (1994) Validation of the tracer-balance concept with reference to leucine: 24-h intravenous tracer studies with $\mathrm{L}-\left[1-{ }^{13} \mathrm{C}\right]$ leucine and $\left[{ }^{15} \mathrm{~N}^{15} \mathrm{~N}\right]$ urea. Am J Clin Nutr 59, 1000-1011.

Forslund AE, Hambraeus L, Olsson RM, El-Khoury AE, Yu YM \& Young VR (1998) The 24-h whole body leucine and urea kinetics at normal and high protein intakes with exercise in healthy adults. Am J Physiol 275, E310-E320.

Fuller NJ, Jebb SA, Laskey MA, Coward WA \& Elia M (1992) Four-compartment model for the assessment of body composition in humans: comparison with alternative methods and evaluation of the density and hydration of fat-free mass. Clin Sci 82, 687-693.

Furst P, Jonsson A, Josephson B \& Vinnars E (1970) Distribution in muscle and liver vein protein of ${ }^{15} \mathrm{~N}$ administered as ammonium acetate to man. J Appl Physiol 29, 307-312.

Gibson N, Ah-Singh E, Badalloo A, Forrester T, Jackson AA \& Millward D (1997) Transfer of ${ }^{15} \mathrm{~N}$ from urea to the circulating dispensable and indispensable amino acid pool in the human infant. Proc Nutr Soc 56, 79 Abstr.

Goldberg G, Black A, Jebb S, et al. (1991) Critical evaluation of energy intake data using fundamental principles of energy physiology: 1. Derivation of cut-off limits to identify under recording. Eur J Clin Nutr 45, 569-581.

Jackson AA (1991) Critique of protein-energy interactions in vivo: Urea kinetics. In Protein-Energy Interactions, pp. 63-79 [N Scrimshaw and B Schurch, editors]. Lausanne: Nestle Foundation.

Jackson AA (1994a) Urea as a nutrient: Bioavailability and role in nitrogen economy. Arch Dis Child 70, 3-4.

Jackson AA (1994b) Is leucine produced by the colonic microflora? (Commentary). Am J Clin Nutr 60, 977-979.

Jackson AA (1998) Salvage of urea-nitrogen in the large bowel: Functional significance in metabolic control and adaptation. Biochem Soc Trans 26, 231-236.

Jackson AA (1999) Limits of adaptation to high dietary protein intakes. Eur J Clin Nutr 53, S44-S52.

Jackson AA, Danielsen M \& Boyes S (1993) A noninvasive method for measuring urea kinetics with a single dose of $\left[{ }^{15} \mathrm{~N}^{15} \mathrm{~N}\right]$ urea in free-living humans. J Nutr 123, 2129-2136.

Jackson AA, Landman J \& Picou D (1981) Urea production rates in man in relation to the dietary intake of nitrogen and the metabolic state of the individual. In Nitrogen Metabolism in
Man, pp. 249-251 [JC Waterlow and ML Stephen, editors]. London: Applied Science Publishers.

Jackson AA, Picou D \& Landman J (1984) The non-invasive measurement of urea kinetics in normal man by a constant infusion of $\left[{ }^{15} \mathrm{~N}^{15} \mathrm{~N}\right]$ urea. Hum Nutr Clin Nutr 38, $339-354$.

Jahoor F, Jackson AA \& Golden MHN (1988) In vivo metabolism of nitrogen precursors for urea synthesis in the postprandial rat. Ann Nut Metabol 32, 240-244.

Johnstone AM, Stubbs RJ \& Harbron C (1996) Effect of overfeeding macronutrients on day-to-day food intake in man. Eur J Clin Nutr 50, 418-430.

Langran M, Moran B, Murphy J \& Jackson AA (1992) Adaptation to a diet low in protein: Effect of complex carbohydrate upon urea kinetics in normal men. Clin Sci 82, 191-198.

Lobley GE, Bremner DM \& Zuur G (2000) Effects of diet quality on urea fates in sheep as assessed by refined, non-invasive $\left[{ }^{15} \mathrm{~N}^{15} \mathrm{~N}\right]$ urea kinetics. Br J Nutr 84, 459-468.

Long C, Jeevanandam M \& Kinney J (1978) Metabolism and recycling of urea in man. Am J Clin Nutr 31, 1367-1382.

Marsh WH, Fingerhut B \& Miller H (1965) Automated and manual direct methods for the determination of blood urea. Clin Chem 11, 624-627.

Meakins T \& Jackson AA (1996) Salvage of exogenous nitrogen enhances nitrogen balance in normal men consuming marginally inadequate protein diets. Clin Sci 90, 215-225.

Metges CC, Petzke KJ, El-Khoury AE, et al. (1999) Incorporation of urea and ammonia nitrogen into ileal and faecal microbial proteins and plasma free amino acids in normal men and ileostomates. Am J Clin Nutr 70, 1046-1058

Millward DJ, Forrester T, Ah-Singh E, et al. (2000) The transfer of ${ }^{15} \mathrm{~N}$ from urea to lysine in the human infant. Br J Nutr 83 , 505-512.

Mitch WE, Lietman PS \& Walser M (1977) Effects of oral neomycin and kanamycin in chronic uremic patients. I. Urea metabolism. Kidney Internat 11, 116-122.

Owen O, Smalley K, D'Alessio D, Mozzoli M \& Dawson E (1998) Protein fat and carbohydrate requirements during starvation: Anaplerosis and cataplerosis. Am J Clin Nutr 68, 12-34.

Pullicino E, Coward WA, Stubbs RJ \& Elia M (1990) Bedside and field methods for assessing body composition: comparison with the deuterium dilution technique. Eur J Clin Invest 40, $753-762$.

Sands JM (2002) Molecular approaches to urea transporters. J Am Soc Nephrol 13, 2795-2806.

Sarraseca A, Milne E, Metcalf M \& Lobley GE (1998) Urea recycling in sheep: Effects of intake. Br $J$ Nutr 79, 79-88.

Scrimshaw N, Hussein M, Murray E, Rand W \& Young VR (1972) Protein requirements of man: Variations in obligatory urinary and fecal nitrogen losses in young men. J Nutr 102, 1595-1604

Torrallardona D, Harris C, Coates M \& Fuller M (1996) Microbial amino acid synthesis and utilization in rats: incorporation of ${ }^{15} \mathrm{~N}$ from ${ }^{15} \mathrm{NH}_{4} \mathrm{Cl}$ into lysine in the tissues of germ free and conventional rats. Br J Nutr 76, 689-700.

Torrallardona D, Harris C, Milne E \& Fuller M (1994) The contribution of intestinal microflora to amino acid requirements in pigs. In Proceedings from 6th International Symposium on Digestive Physiology in Pigs, pp. 245-248 [WB Souffiant and $\mathrm{H}$ Hagemeister, editors]. Wageningen: Dummerstoif Forsch Inst Biol Landwirtsch Nutztiere.

Van Gaal LF (1998) Dietary treatment of obesity. In Handbook of Obesity, pp. 875-890 [GA Bray, C Bouchard and WPT James, editors]. New York: Marcel Dekker.

Varcoe R, Halliday D, Carson E, Richards P \& Tavill A (1975) Efficiency of utilization of urea nitrogen for albumin synthesis 
by chronically uremic and normal man. Clin Sci Mol Med $\mathbf{4 8}$, 379-390.

Watson P, Watson I \& Batt R (1980) Total body water volumes for adult males and females estimated from simple anthropometric measurements. Am J Clin Nutr 33, 27-39.

Weijs PJM, Calder AG, Milne E \& Lobley GE (1996) Conversion of $\left[{ }^{15} \mathrm{~N}\right]$ ammonia into urea and amino acids in humans and the effect of nutritional status. Br J Nutr 76, 491-499.

World Health Organization (1985) Principles for estimating protein requirements. In Energy and Protein Requirements. Report of a Joint FAO/WHO/UNU Expert Consultation, Technical Report Series no. 724, pp. 52-70. Geneva: WHO.

Yaboah N, Ah-Singh E, Badalloo A, Forrester T, Jackson AA \&
Millward D (1996) Transfer of ${ }^{15} \mathrm{~N}$ from urea to the circulating lysine pool in the human infant. Proc Nutr Soc 55, 37 Abstr. Young VR \& El-Khoury AE (1994) Reply to A. A. Jackson (Commentary). Am J Clin Nutr 60, 978-979.

Young VR, El-Khoury AE, Raguso CA, Forslund AH \& Hambraeus L (2000) Rates of urea production and hydrolysis and leucine oxidation change linearly over widely varying protein intakes in healthy adults. $J$ Nutr 130, 761-766.

Young VR, Yu Y \& Fukagawa N (1992) Whole body energy and nitrogen (protein) relationships. In Energy Metabolism: Tissue determinants and Cellular Corollaries, pp. 139-161 [JM Kinney and HN Tucker, editors]. New York: Raven Press. 